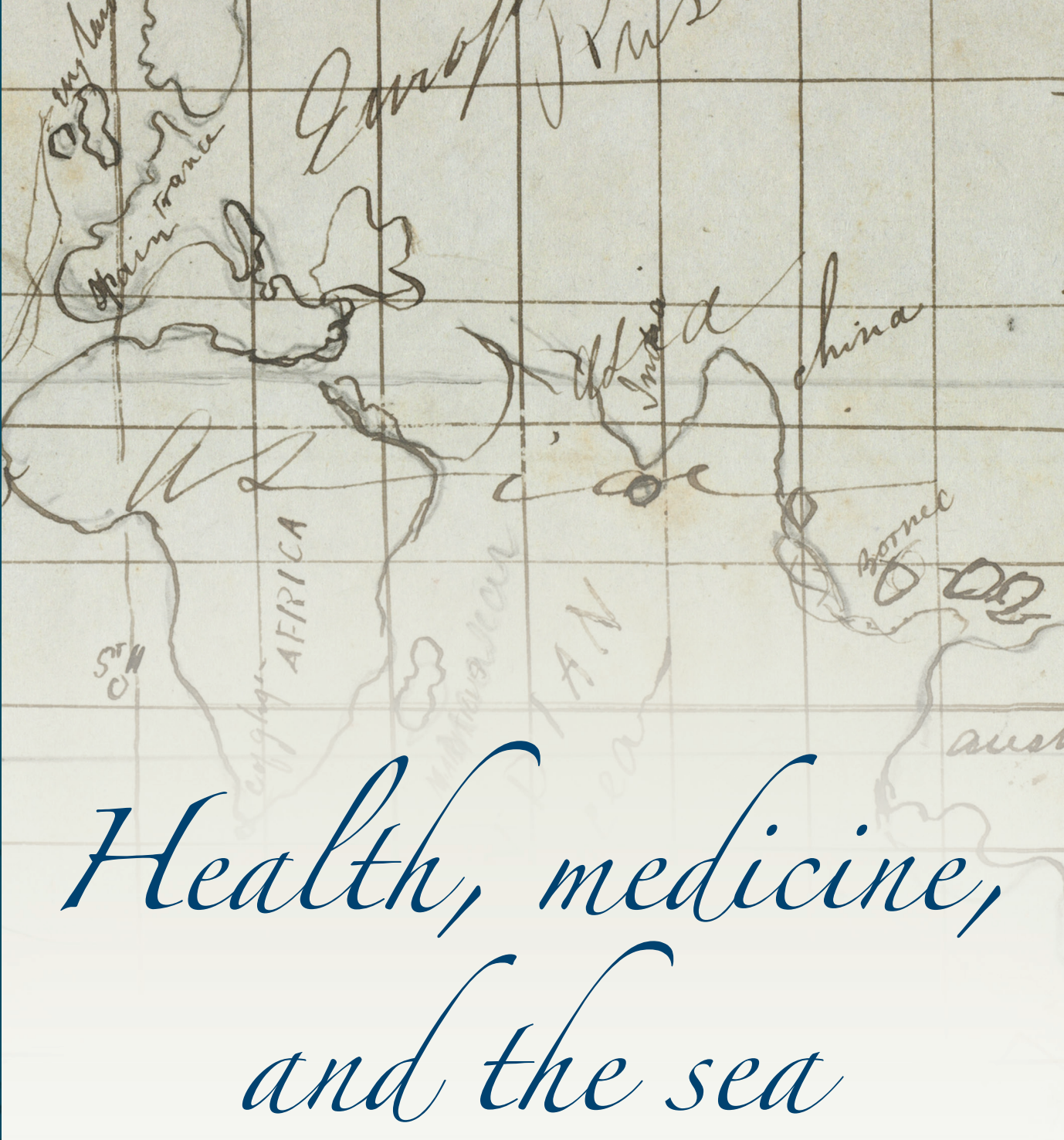

AUSTRALIAN VOYAgES C.I $8 \mid 5-1860$

Katherine Foxhall 
Health, medicine, and the sea

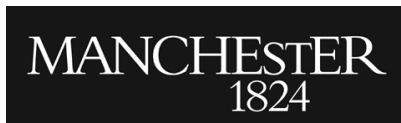

Manchester University Press 
Katherine Foxhall - 9781526130150

Downloaded from manchesterhive.com at $04 / 26 / 2023$ 11:56:39AM 


\title{
Health, medicine, and the sea
}

\author{
Australian Voyages, \\ c.1815-1860
}

Katherine Foxhall

Manchester University Press 
Copyright (C) Katherine Foxhall 2012

The right of Katherine Foxhall to be identified as the author of this work has been asserted by her in accordance with the Copyright, Designs and Patents Act 1988.

Published by Manchester University Press

Altrincham Street, Manchester M1 7JA, UK

www.manchesteruniversitypress.co.uk

British Library Cataloguing-in-Publication Data is available

Library of Congress Cataloging-in-Publication Data is available

ISBN 9781784993610 paperback

First published by Manchester University Press in hardback 2012

The publisher has no responsibility for the persistence or accuracy of URLs for any external or third-party internet websites referred to in this book, and does not guarantee that any content on such websites is, or will remain, accurate or appropriate. 